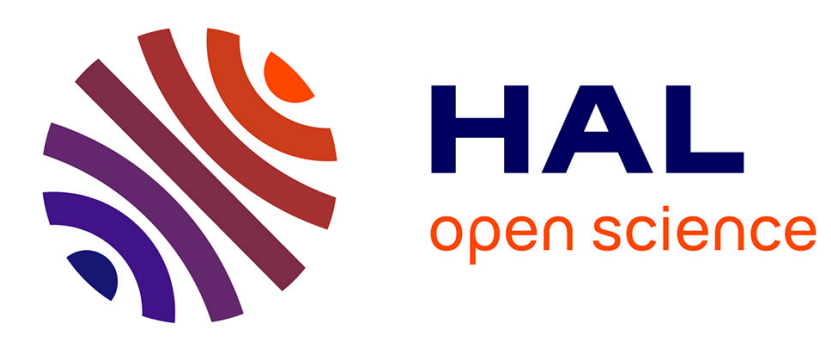

\title{
The Determinants of Bank Stock Returns' Co-Movements in East Asia
}

Carlos Bautista, Philippe Rous, Amine Tarazi

\section{To cite this version:}

Carlos Bautista, Philippe Rous, Amine Tarazi. The Determinants of Bank Stock Returns' CoMovements in East Asia. 2008. hal-00916496

\section{HAL Id: hal-00916496 \\ https://hal-unilim.archives-ouvertes.fr/hal-00916496}

Preprint submitted on 10 Dec 2013

HAL is a multi-disciplinary open access archive for the deposit and dissemination of scientific research documents, whether they are published or not. The documents may come from teaching and research institutions in France or abroad, or from public or private research centers.
L'archive ouverte pluridisciplinaire HAL, est destinée au dépôt et à la diffusion de documents scientifiques de niveau recherche, publiés ou non, émanant des établissements d'enseignement et de recherche français ou étrangers, des laboratoires publics ou privés. 


\title{
The determinants of bank stock returns' co-movements in East Asia
}

\author{
Carlos Bautista ${ }^{a}$, Philippe Rous ${ }^{\mathrm{b}}$ and Amine Tarazi ${ }^{\mathrm{b}}{ }^{*}$ \\ ${ }^{\mathrm{a}}$ University of the Philippines, CBA, Diliman, Quezon City 1101, Philippines \\ ${ }^{\mathrm{b}}$ Université de Limoges, LAPE, 5 rue Félix Eboué, 87031 Limoges, France
}

\begin{abstract}
We examine co-movements of bank stock returns in eight East Asian countries after the 1997 crisis and attempt to determine the factors that influence them. The return correlations among banks within each country are computed and used as a dependent variable in weighted least squares regressions. The factors were chosen from a wide range of accounting and market-based indicators using a stepwise procedure. The results show that the share of interbank activities in the balance sheet does not explain the level of correlations. However, a strong link is found between the bank return co-movements and bank default risk measured by a z-score. To a lesser extent, the share of loan activities in a bank's balance sheet, which is a proxy of opacity, is also a significant factor of the level of correlation.
\end{abstract}

Keywords: Bank contagion, East Asia, Correlation of bank stock returns

JEL classification: G21, G29

\section{Introduction}

Banking system failures often lead to a deceleration of economic activity that turns into a deep crisis. We try to determine the possible reasons for banking system breakdowns, which can be deduced from the characteristics of member institutions. Problems of a systemic nature have been extensively examined in the banking and finance literature; but while banking sector systemic risk analysis has thrived in developed economies, there are only a few studies of bank domestic contagion for the Asian region. ${ }^{1}$ In most of these studies, systemic risk is measured by the comovement of bank stock returns within a country.

We use correlation measures to analyze the movements of bank stock returns. We however go one step further by investigating the factors that influence the magnitude of these correlations

\footnotetext{
*Corresponding author. Tel. : +33 5551492 36, Email : tarazi@unilim.fr

1 See the following and their references: De Nicolo and Kwast (2002), Demirgüç-Kunt et al (2006), Gropp and Vesala (2005) and Gropp and Moermann (2004). For an extensive analysis of the Asian Crisis, see Baig and Goldfajn (1998).
} 
and therefore what variables policy makers could monitor when attempting to detect breakdowns in financial systems. We follow a two-step empirical procedure. Exponentially weighted moving-average correlations of market-adjusted bank stock returns are first computed. These are then averaged for each bank and used as the dependent variable in a cross-section regression with various accounting and market-based indicators as regressors. The countries covered by this study are Hong Kong, Indonesia, Korea, Malaysia, Philippines, Singapore, Taiwan, and Thailand.

\section{Methodology and Data}

We proceed in two steps. First, for each country the correlations of weekly stock return data of every individual bank with all the other banks are computed. Second, the average correlation of each bank with the other banks is used as the dependent variable in a cross-section equation with accounting and market-based variables as regressors. These variables are introduced to capture various bank specific characteristics such as size, performance, opacity, illiquidity, and risk.

To isolate the contagion effects, the influence of market movements are filtered out by using the residuals of a standard market model:

$$
\mathrm{R}_{\mathrm{it}}=\alpha_{\mathrm{i}}+\beta_{\mathrm{i}} \mathrm{R}_{\mathrm{m}(\mathrm{i}) \mathrm{t}}+\mathrm{r}_{\mathrm{it}}
$$

$R_{i t}=\log \left(P_{i, t} / P_{i, t-1}\right)$ is the bank $i$ stock return, $\mathrm{R}_{\mathrm{m}(\mathrm{i}) \mathrm{t}}=\log \left(\mathrm{P}_{\mathrm{m}(\mathrm{i}), \mathrm{t}} / \mathrm{P}_{\mathrm{m}(\mathrm{i}), t-1}\right)$ is the market return computed on the basis of domestic indexes, and $r_{i t}$ is the filtered bank return, which is the residual of an OLS regression of equation (1). The $P_{i, t} \mathrm{~s}$ are the stock prices.

The correlation of bank $i$ stock return with all the other bank returns indexed by $j$, within the same country, is an exponentially weighted moving-average correlation between $r_{i, t}$ and $r_{j, t}$ evaluated at time $t$ : 


$$
\rho_{i j, t}=\frac{\sum_{s=0}^{k} \lambda^{s} r_{i, t-s} r_{j, t-s}}{\left[\left(\sum_{s=0}^{k} \lambda^{s} r_{i, t-s}^{2}\right)\left(\sum_{s=0}^{k} \lambda^{s} r_{j, t-s}^{2}\right)\right]^{1 / 2}}
$$

The lag length $k$ is set to 51 , and $\lambda=0.94$ as in Engle (2002). The co-movements of a given bank's return with the returns of all the other banks established in the same country are then averaged across all years:

$$
\bar{\rho}_{i}=\frac{1}{N} \sum_{j=1}^{N} \frac{1}{T} \sum_{t=1}^{T} \rho_{i j, t} \text { for } \mathrm{j} \neq \mathrm{i}
$$

The second step in the process conducts a cross-section WLS regression of the average correlation of bank $i$ as defined in (3) against $m$ market-based and accounting variables:

$$
\bar{\rho}_{\mathrm{i}}=\lambda_{0}+\lambda_{1} \mathrm{x}_{\mathrm{i} 1}+\ldots+\lambda_{\mathrm{m}} \mathrm{x}_{\mathrm{im}}+\varepsilon_{\mathrm{i}}
$$

To avoid the consequences of the heteroskedastic nature of the calculated $\bar{\rho}_{\mathrm{i}}$, we use the weighted least squares method where all the variables of the model are weighted by the estimated standard deviation $\mathrm{s}\left(\bar{\rho}_{\mathrm{i}}\right)$ of $\bar{\rho}_{\mathrm{i}}$ :

$$
s\left(\bar{\rho}_{i}\right)=\sqrt{\frac{\frac{1}{N} \sum_{j=1}^{N} \frac{1}{T} \sum_{t=1}^{T}\left(\rho_{i j, t}-\bar{\rho}_{i}\right)^{2}}{N T}}
$$

Weekly stock price data were obtained from Datastream from 2000 to 2005 to compute market adjusted returns, correlations, and market-based regressors. The accounting-based explanatory variables, which are averaged over the 2000-2005 period, use bank balance sheet and income statement data that come from Bankscope. After eliminating the banks with inactively traded stocks, the sample is restricted to 122 banks from the eight countries. Sixty seven accounting and market-based indicators are used, which can be categorized into nine groups: size, capital adequacy, asset quality, earnings, liquidity, interbank activity, balance sheet 
structure, income statement structure, and market risk indicators (systematic risk, specific risk, total risk and default risk measured by a z-score (Boyd and Graham (1986)). Because of the large number of accounting and market-based indicators, we conduct stepwise regressions on Equation (4) to isolate the variables that have the best explanatory power. ${ }^{2}$

\section{Hypotheses and Estimation Results}

Our aim is to study the determinants of co-movements of stock prices within the banking industry. We focus on the correlations of the residuals of the market model to consider firmspecific risk and how this might affect other firms in the same industry. Because intermediation theory considers banks as opaque firms (Diamond,1984), specifically banks heavily involved in the transformation of deposits in loans (asymmetric information), market participants are expected to react promptly to any bad news affecting a specific bank by overselling stocks of such financial institutions. Also, because banks are subject to runs (Diamond and Dybvig, 1983), potentially illiquid institutions and particularly those that are more reliant on deposits are vulnerable to a specific negative shock affecting any other firm in the industry. Alternatively, intra-industry links, which are an important feature of the banking industry (interbank operations) and a major source of contagion, should play a prominent role in the reaction of market participants. A negative event (decrease in the stock return) of a given institution is more likely to affect other institutions that are more involved in interbank lending and/or interbank deposits. Eventually, higher risk taking and higher default risk is also expected to increase the vulnerability of a given bank. We therefore consider standard accounting-based and marketbased risk indicators as potential explanatory variables.

To check for robustness and because we are specifically concerned about co-movements of negative returns, the dependent variable is defined in two ways. We first consider the correlation

\footnotetext{
2 Due to space constraint the full list of variables and the descriptive statistics are not included but are available from the authors on request.
} 
of all the returns (negative or positive). We also compute the dependent variable by taking the correlations of simultaneously negative returns only. To ensure that our results are not influenced by a high variability in the correlations of an individual bank's stock returns with the returns of all the other banks, we also run the regressions on a sample restricted to observations of the dependent variable with a coefficient of variation lower than 2. In other words, because the dependent variable is the mean correlation of returns of a given bank with the returns of all the other banks, we need to make sure, for each bank, that a high (low) average correlation is consistent with high (low) individual correlations and that high correlations are not partially offset by low correlations. Eventually, to further check for robustness, we re-estimate the equations induced by the stepwise process on bootstrapped samples (10000 replications).

Table 1 shows the results of two sets of WLS stepwise regressions corresponding to the two definitions of the dependent variable. A dummy variable, that takes the value of 1 for Singapore, Hong Kong and Taiwan and 0 otherwise, was included in the regressions to account for differences in financial development. This dummy also reflects the differences in inflation and growth levels. These three countries present the lowest levels of both inflation and growth. The table shows that correlations are significantly higher for more financially developed countries. Higher default risk as measured by a lower value of the $\mathrm{z}$-score ${ }^{3}$ is associated with a higher value of the dependent variable. A larger share of loan activities in total assets (opacity proxy) is also associated with higher correlations in the specification where all of the returns (negative or positive) are taken into account. When only negative returns are considered, the z-score variable is still significant along with the ratio of loan loss provisions to net interest revenue (proxy of exposure to credit risk).

${ }^{3} \mathrm{z}$-score is defined as : $\frac{1+\overline{\mathrm{R}}_{\mathrm{i}, \mathrm{t} \mid \mathrm{t}-51}}{\sigma\left(\mathrm{R}_{\mathrm{i}, t \mid t-51}\right)}$ where $\overline{\mathrm{R}}_{\mathrm{i}, \mathrm{t} \mid \mathrm{t}-51}$ and $\sigma\left(\mathrm{R}_{\mathrm{i}, \mathrm{t}} \mid \mathrm{t}-51\right)$ are, respectively, the mean and the standard deviation of bank i returns within a $[t-51, t]$ interval. In our cross section regressions we consider the mean value of the score for each bank over the 2000-2005 period. 


\section{Conclusion}

The aim of this paper is to analyze the co-movements of stock prices of 122 banks in East Asia. We find a strong link between the co-movements of residuals and bank default risk measured by a z-score and to a lesser extent with the share of loan activities in the balance sheet, which is considered as a proxy of bank opacity. However, interbank activity is not a significant factor of co-movements. Our results suggest that market participants are less concerned about liquidity and mainly consider the level of default risk (probability of failure) when they take the decision of selling bank stocks when a negative event affects a given bank in the banking system. 
Table 1: Stepwise WLS regressions

Estimated Equation : $\bar{\rho}_{\mathrm{i}}=\lambda_{0}+\sum_{\mathrm{k}=1}^{\mathrm{m}} \lambda_{\mathrm{k}} \mathrm{X}_{\mathrm{ik}}+\gamma_{1}$ findev $_{\mathrm{i}}+\varepsilon_{\mathrm{i}}$ where $\bar{\rho}_{\mathrm{i}}=\frac{1}{\mathrm{~N}} \sum_{\mathrm{j}=1}^{\mathrm{N}} \frac{1}{\mathrm{~T}} \sum_{\mathrm{t}=1}^{\mathrm{T}} \rho_{\mathrm{ij}, \mathrm{t}}$ for $i \neq j$

Findev is a dummy variable which equals 1 for Singapore, Hong Kong, Taiwan and zero otherwise. The explanatory variables $x_{i k}$ are selected on the basis of a stepwise procedure where the selection criterion is a threshold P-Value of the estimated coefficient of $5 \%$. The stepwise procedure is carried out on the full (unrestricted) sample. The equation is subsequently estimated on, first, a restricted sample of banks for which the coefficient of variation of the mean correlation is lower than 2 and, second, on the basis of 10000 bootstrapped samples. There are two sets of results : "All correlations" (the individual pairwise correlations are evaluated on the basis of all the returns) and "Correlations of Negative returns" (the individual pairwise correlations are only evaluated for returns that are simultaneously lower than zero). ${ }^{* * *}, * *$ and ${ }^{*}$ indicate significance respectively at the $1 \%, 5 \%$ and $10 \%$ levels.

\begin{tabular}{|c|c|c|c|c|c|c|}
\hline \multirow{2}{*}{$\begin{array}{c}\text { All correlations } \\
\text { Variable }\end{array}$} & \multicolumn{2}{|c|}{ Unrestricted sample } & \multicolumn{2}{|c|}{ Restricted } & \multicolumn{2}{|c|}{ Bootstrapped } \\
\hline & Coef & t-stat & Coef & t-stat & Coef & t-stat \\
\hline Mean z-score ${ }^{1}$ & $-0.010^{* * *}$ & -7.309 & $-0.011^{* * *}$ & -5.911 & $-0.009^{* * *}$ & -6.280 \\
\hline Capital funds/net loans & $-0.001^{* * *}$ & -2.577 & $0.001^{* * *}$ & 0.824 & -0.001 & -0.658 \\
\hline Net loans/total assets & $0.003^{* * *}$ & 5.134 & $0.003^{* * *}$ & 3.393 & $0.003^{* * *}$ & 3.645 \\
\hline Findev & $0.161^{* * *}$ & 8.460 & $0.166^{* * *}$ & 7.835 & $0.155^{\star * *}$ & 6.676 \\
\hline Constant & $0.138^{* * *}$ & 2.802 & $0.195^{* * *}$ & 2.755 & $0.143^{*}$ & 1.944 \\
\hline No. Of Observations & \multicolumn{2}{|c|}{75} & \multicolumn{2}{|c|}{45} & \multicolumn{2}{|c|}{75} \\
\hline Adj. Unweighted $R^{2}$ & \multicolumn{2}{|c|}{0.670} & \multicolumn{2}{|c|}{0.612} & \multicolumn{2}{|c|}{-} \\
\hline \multicolumn{7}{|l|}{ Correlations of negative returns only } \\
\hline Variable & Coef & t-stat & Coef & t-stat & & \\
\hline Mean z-score & $-0.005^{* * *}$ & -4.361 & $-0.005^{\star * *}$ & -4.370 & $-0.005^{\star * *}$ & -3.547 \\
\hline Loan loss provisions/net interest revenue & $0.001^{* * *}$ & 3.833 & $0.001^{* * *}$ & 3.687 & $0.001^{* *}$ & 2.312 \\
\hline Loan loss provisions/gross loans & $-0.011^{* * *}$ & -2.925 & $-0.012^{* * *}$ & -3.304 & -0.008 & -1.021 \\
\hline Findev & $0.083^{* * *}$ & 5.833 & $0.076^{* * *}$ & 5.636 & $0.089^{* * *}$ & 4.889 \\
\hline Constant & $0.355^{* * *}$ & 12.793 & $0.367^{* * *}$ & 13.390 & $0.331^{* * *}$ & 8.829 \\
\hline No. Of Observations & \multicolumn{2}{|c|}{75} & \multicolumn{2}{|c|}{70} & \multicolumn{2}{|c|}{75} \\
\hline Adj. Unweighted $R^{2}$ & \multicolumn{2}{|c|}{0.502} & \multicolumn{2}{|c|}{0.445} & \multicolumn{2}{|c|}{-} \\
\hline
\end{tabular}

${ }^{1}$ : See footnote 3 for the definition of this variable. 


\section{References}

Baig, T. and I. Goldfajn (1998), Financial market contagion in the Asian crisis, IMF working paper no. 98/155.

Boyd, J. and S. Graham (1986), Risk, regulation and bank holding company expansion, Federal Reserve Bank of Mineapolis Quarterly Review.

De Nicolo, G. and M. Kwast (2002), Systemic risk and financial consolidation. Are they related ? Journal of Banking and Finance 26, 861-880.

Diamond D.W., 1984, "Financial Intermediation and Delegated Monitoring", Review of Economic Studies, 393-414.

Diamond D and P. Dybvig (1983): "Bank runs, deposit insurance and liquidity", Journal of Political Economy, 91(3), 400-409.

Demirgüç-Kunt A., Detragiache E., and P. Gupta (2006), Inside the crisis: An empirical analysis of banking systems in distress, Journal of International Money and Finance, 25(5), 702-718.

Engle, R. ( 2002), Dynamic conditional correlation: a simple class of multivariate GARCH, Journal of Business and Economic Statistics 17 (5), 425-446.

Gropp, R. and G. Moermann (2004), Measurement of contagion in banks' equity prices, Journal of International Money and Finance 23(3), 405-459.

Gropp and Vesala (2005), Measuring bank contagion using market data, unpublished manuscript. 